\title{
The Research on Dimensions of Home Country Culture of International Brand
}

\author{
Wei-Hong ZHAO ${ }^{a, \star}$, Ming-Yue $\mathrm{YI}^{\mathrm{b}}$ \\ Business School, Jiangxi Normal University, Nanchang, China \\ azwh4005@sina.com, b2483464131@qq.com
}

Keywords: Home country cultural resource, Brand internationalization, Cultural strategy.

\begin{abstract}
The aimof this article is to use the home country culture to shape international brands to help the brand internationalize. Through literature review, this paper puts forward the conceptual model of home country culture. This paper argues that home country cultural resource including cultural symbols, character images, and theme stories. The three types of national cultural resource construct the strategies of brand symbolization, personification and narration, and explain how to transform the cultural resource into a brand element that can be used for internationalized operation and win international consumers ' welcome. How to use the cultural resource of home country to shape international brand, the implementation of differentiation strategy has a certain guiding significance.
\end{abstract}

\section{Introduction}

In the innovation-driven development of today, the core competitiveness of enterprises not only from High-tech technology, embedded in the brand culture is more important. For consumers, the consumption of a certain brand is a potential cultural identity, creating a subconscious desire to consume.The globalization of economy and politics has produced cultural trends, such as "Tang Feng", "Korean Flow" and "European and American Style", which has exerted an increasingly far-reaching influence on people's consumption behavior (su, 2008). Some brands exploit the cultural resources characteristics of the home country to exploit the international market (kapferer,2006 Meng Fanyi, 2016) in order to bring the difference of product/service to foreign consumers through the unique cultural elements (Kumar and steen-kamp,2013), And won the host country's consumer assets. For example, China's "Bai Cao Ji", "French Blue Porcelain" (Hejia news, 2013, Liu Biao, 2015), France's "Chanel", the United States "Starbucks", "McDonald's" are favored by the host consumers. Creating international brands with cultural resources is an effective strategic tool for brand internationalization (Hejia, 2013). However, China's "Going out" is OEM, low-priced, competitive exports for a long time. China is the world's second largest foreign investor and the first manufacturing nation, but the number of Chinese brands that foreign consumers recall is a handful, concentrating on consumer electronics, such as Huawei, Lenovo, ZTE and Haier. And nearly 40\% of consumers believe that Chinese manufacturing "poor quality, low and unreliable" (jwt, 2012), in terms of reputation, trust, value and familiarity of the evaluation is significantly inferior to Western brands and Japanese and Korean brands (Laforet\& chen, 2010). In addition, they have a preference for brands from developed or Home-grown (Bilkey and nes, 1982; Batra, 2000; sharma, 2011). Faced with this stereotype and consumer psychology, the brand international road is difficult. But the existing research mainly takes the concept of cultural resources as an abstract, the whole concept, plus the consumer of the brand aesthetic, values, etc. have different understanding, the use of carelessness may lead to consumer negative reaction. Enterprises are eager to know how to translate cultural resources into a brand element that can be internationalized and can win international consumer's welcome. What cultural strategies can be used to shape international brands? All of this will be studied in the paper. 


\section{Cultural Resource}

Cultural resource is the form and content of the etymology, which can be inherited and used in human culture. In the past 20 years, the concept of cultural resource has been widely used in the media, but the academic circle has not yet accepted the strict definition. Scholars (Chang, 1997; Ying Zhang did, 2009; Cao Guangyu, 2008) think that cultural resources in the narrow sense refers to people can produce direct and indirect economic interests of the spiritual and cultural content. Scholars (Dan Zeng, 2006) point out that cultural resource refers toAll the cultural achievements in the process of human development, as well as activities, objects, events, celebrities and famous cities that carry a certain cultural significance." Some scholars (Stiping, 2007) believe that cultural resource is based on tangible resources (ruins, cultural relics, ancient buildings, etc.) or intangible resources (text, language, music, etc.) form appears, carrying a certain ideological significance and spiritual value, so it is objective, real, and non-renewable. Some scholars (Hejia, 2014; Peng, 2011) from the perspective of marketing and communication, the author thinks that cultural resource refers to the symbols, spiritual connotations or objects which are closely related to culture from cultural tradition or in the development of modern society. In this paper, the cultural resources refer to the symbols, spiritual connotations or objects that can be identified by the host country consumers and used by enterprises, which will help the brand internationalization finally.

\section{The Dimension of Cultural Resource}

The essence of brand internationalization is to create the host country consumer brand assets (Jeryl and Fernando, 2007). A country's unique and rich culture is of course the most important asset of the brand country. But in fact, the unique and rich culture is only brand resources, rather than brand equity. only through strategic planning and scientific operation, it can be converted into effective brand assets (Xu Jing, 2016). Many scholars have studied the dimension of cultural resource from the perspective of enterprise and brand. Hofstede (1990) presents the cultural onion model, which consists of symbols, heroes, rituals and core values. Qian Mu and Pang Pak (1998) believe that cultural resources, including material culture, institutional culture and spiritual culture, but they are abstract and have lower level guidance forenterprise. In view of the many research dimension researchers, the author sums up the structural dimensions of cultural resources, as shown in table 1

Table 1. Previous dimensions of cultural resource

\begin{tabular}{|c|c|c|}
\hline Cultural subject & Structural dimension & Researcher \\
\cline { 2 - 3 } enterprise & Symbols, ceremonies, heroes, core values & Hofstede(1990) \\
\cline { 2 - 3 } & $\begin{array}{c}\text { Material culture, institutional culture and } \\
\text { spiritual culture }\end{array}$ & Qian Mu, Pang Pak, 1998 \\
\cline { 2 - 3 } & $\begin{array}{c}\text { Material, social relations, spirit, art, customs, } \\
\text { language symbols }\end{array}$ & Dainian, Fang Keli, 1994 \\
\hline \multirow{5}{*}{ Brand } & $\begin{array}{c}\text { Benefintension, information network, } \\
\text { begnition, emotion attribute, cultural } \\
\text { tradition, individuality image }\end{array}$ & Chen Lilin (2007) \\
\cline { 2 - 3 } & $\begin{array}{c}\text { Corporate culture, products and services, brand } \\
\text { reputation, brand ownership }\end{array}$ & Zhang Hongxia(2009) \\
\cline { 2 - 3 } & $\begin{array}{c}\text { Brand-related language, aesthetic taste, values, } \\
\text { consumer customs, moral norms, lifestyles, } \\
\text { etc. }\end{array}$ & $\begin{array}{c}\text { Hu Mo, Xia } \\
\text { Jianming(2011) }\end{array}$ \\
\hline
\end{tabular}

Cartwright(2004)is believed that no matter what kinds, it is cultural carrier (images, words, etc.), cultural rules (behavior, events, rituals, etc.) and cultural patterns (social context) constitute. This paper divides cultural resources dimension into cultural symbol, character image and theme story. 
Among them, cultural symbols, refers to the formation of historical accumulation, only by the members of a certain cultural group common identity of the typical image, is often with complex meaning of words, names, logos, patterns and objects. The formation of cultural symbols symbolizes the formation of cultural core values, which contributes to the inheritance and dissemination of cultural characteristics and culture. In overseas communication, cultural symbols can leave an intuitive impression on the audience (2014); The character image, refers to the history and the modern times positive, the individuality, the characteristic distinctive character, may be the actual existence character, also may be the fictitious character. To promote the image of the international consumers to understand the national or national brand image; The theme story, refers to the novel, the Folktale, the historical fable, the myth fable, the drama and so on resources, digs the cultural theme story to be helpful to enrich the brand story content, creates the moving brand story.

\section{Brand Culture Strategy}

American scholar Leine Keller pointed out: "Brand elements are those used to mark and differentiate the brand logo design, including brand name, Icon, voice, advertising language and packaging." The external embodiment of these brands is not only the sensory recognition symbol, but also strengthens the brand consciousness, promotes the brand association powerful tool. In the case of lack of understanding of the consumer, it is possible for the brand to produce a positive cultural connotation only by the sensory experience of the external factors (Kotler, 2009; Lee Haiting, 2006). Brand culture strategy includes two strategies, positioning and communication. The brand culture of this paper is located in the cultural resources of home country, from cultural resources of cultural symbols, characters and theme stories of three major cultural resources, the construction of brand symbolic, personification and narrative communication strategies, and consumer motives will match the core of the essence into a recognizable identity, the spread of brand values, brand personality, brand image.

In the brand culture content dissemination, through the symbolic strategy. Enterprises can use text, cultural symbol resources such as name, logo, pattern and object, apply to brand elements such as brand name, icon, sound, advertising language and packaging, so that consumers are strongly associated with the values, needs and desires of specific culture, establish consumer identifiable visual system and convey brand image. Through the personification strategy, the characters and personalities of the cultural resources are refined, which can be transformed into the characters of the brand internationalization and the personality of the brand. Through the narrative strategy, to create moving brand story content, the cultural theme of the story into the story of the internationalization of the brand, the spread of brand connotation, core values and so on, so that it deep the understanding of brand meaning, resonate, so as to better shape and spread the international brand.

In the choice of brand culture channels, mainly divided into traditional media (television, newspapers) and emerging Media (network media). Enterprises can use events such as emergencies, public events, focus events, focus and charitable activities to enhance the corporate brand culture influence.

\section{Conclusion}

Through literature review, this paper puts forward the conceptual model of home country culture. including home country cultural resources can help the brand internationalize from the three aspects of cultural symbols, character images, and theme stories.However, this research also has limitation. This research is mainly built on the basis of literature review, then lack of empirical data inspection. Therefore, the focus of the next research is based on literature review and interview, following is scale development, research design, data collection and analysis, using an empirical analysis of the scientific method to test adequacy of the model. 


\section{Acknowledgment}

We are grateful for the financial support of the National Natural Science Foundation of China (71762019), the Social Science Planning Key Project (17GL02) offered by Jiangxi Provincial Association of Social Sciences, and Jiangxi University Humanities and Social ScienceProject(GL17116). and the 2017 Postgraduate Innovation Foundation Project offered by Jiangxi Normal University(YJS2017048).

\section{References}

[1]Hofstede, G. H.. Culture`s Consequences: Comparing Values,Behaviors, Institutions, and Organizations across Nations:SAGE Press, 2001.

[2]Douglas. B. H. Brand and Brand Building. Boston: Harvard School Publications, 2002

[3]Alden D L, Batra R. Brand Positioning Through Advertising in Asia, North America, and Europe: The Role of Global Consumer Culture[J]. Journal of Marketing, 1999, 63(1):75-87

[4]Westjohn. S A,SinghN,Magnusson P. Responsiveness to global and local consumer culture positioning:A personality and collective identity perspective[J]. Journal of International Marketing, 2012,20(1):58-73.

[5]Gammoh B S, Koh A C, Okoroafo S C. Consumer culture brand positioning strategies: an experimental investigation[J]. Journal of Product \& Brand Management, 2011, 20(1):48-57.

[6]T A. How Brands Become Icons: The Principles of Cultural Branding[J]. Journal of Advertising Research, 2005, 45(2):282-283.

[7]XieY,BatraR,Peng S Q. An extended model of preference formation between global and local brands:The roles of identity expressiveness,trust,and affect[J]. Journal of International Marketing, 2015,23(1):50-71.

[8]Su, Lee Zhina. The influence of foreign cultural identity on consumers ' purchasing behavior and its enlightenment--taking the hallyu trend as an example [J]. Marketing Guide, 2008 (2): 39-42.(in Chinese)

[9]Zhao Weihong, Tokuyama, Zhu Haiqing. Research on the driving mechanism and strategy of regional branding based on resources and system [J]. Macroeconomic studies, 2015 (2): 26-38.(in Chinese)

[10]W. Zhao, R. Sun, N. Kakuda, Institutionalized place branding strategy, interfirm trust, and place branding performance: Evidence from China , Journal of Business Research.78(2017) 261-267.

[11]Liu Ying, NieChunyan, Zhang Yi. Research on Chinese brand archetype strategy under the background of globalization [J]. Managing the World, 2016 (4): 182-183. (in Chinese)

[12]Carvalho S W, Samu S, Sivaramakrishnan S. The Effect of Country-Related Brand AssociProduct Attributes on Attitude toward Unfamiliar Foreign Brands: A Schema Congruity Persp Journal of International Consumer Marketing, 2011, 23: 135-150.

[13]Kaynak E, Cavusgil S. Consumer attitudes towards products of foreign origin: do they product classes? [J]. International Journal of Advertising, 1983, 2: 147-157.

[14]Özsomer A, Altaras S. Global brand purchase likelihood: A critical synthesis and an integrated conceptual framework[J].Journal of International Marketing, 2008, 16(4): 1-28. 